\title{
EFEK GENISTEIN TOPIKAL TERHADAP EKSPRESI IL-8 PADA KORNEA TIKUS (RATTUS NOVERGICUS STRAIN WISTAR) MODEL INFLAMASI (TRAUMA KIMIA BASA)
}

\author{
Zuhal Afkar Zulkarnain ${ }^{1}$, Alva Sylvestris ${ }^{2}$, Ruby $\mathbf{R}^{3}$ \\ Fakultas Kedokteran, Universitas Muhammadiyah Malang, J1. Bendungan Sutami No. 188A, Malang, 65145, \\ Indonesia, 0341-551149
}

\begin{abstract}
ABSTRAK
Efek Genistein Topikal Terhadap Ekspresi IL-8 Pada Kornea Tikus (Rattus novergicus strain wistar) Model Inflamasi (Trauma Kimia Basa). Latar Belakang: Inflamasi kornea adalah penyakit mata yang paling sering menyebabkan kebutaan. Genistein sebagai anti-inflamasi dapat menghambat IL-8. Tujuan: Mengetahui pengaruh pemberian genistein terhadap ekspresi IL-8 kornea tikus model inflamasi. Metode: The Post Test Only Control Group Design. Hasil dan Diskusi: Uji ANOVA menyimpulkan bahwa terdapat perbedaan bermakna ekspresi IL-8 pada berbagai kelompok perlakuan (Sig $0.000<\mathrm{p}(0.05))$. Kesimpulan: Pemberian genistein topikal tetes mata pada kornea tikus putih jantan dapat menurunkan ekspresi IL-8.
\end{abstract}

\begin{abstract}
The Effect of Topical Genistein on the Expression of IL-8 At Corneal Rats (Rattus novergicus strain wistar) Model of Inflammation (Alkali Chemical Injury) Introduction: Corneal inflammation is the most common eye disease that causes blindness. Genistein as an anti-inflammatory could inbibit IL-8. Objective: To detect the effect of genistein on the expression of IL-8 corneal rats model of inflammation (alkali chemical injury). Method: The Post Test Only Control Group Design Result: From the results of ANOVA test it was concluded that there were significant differences between-group in expression of IL-8 levels (Sig $0.010<p(0.05))$ ). . Conclusion: The outpouring of ophthalmic topical genistein on the cornea white male rats (rattus novergicus strain wistar) could reduce the expression of IL-8.
\end{abstract}

Keywords: mosquito coil, COPD.

\section{PENDAHULUAN}

Pada saat ini banyak ditemukan kejadian yang berkaitan dengan inflamasi dan trauma pada kornea. Sebagian besar dialami oleh orang-orang yang banyak beraktivitas di luar ruangan. Setiap hari mereka banyak terkena oleh faktorfaktor yang banyak menyebabkan iritasi pada mata dan kornea seperti debu, polusi udara, dan sinar matahari langsung. Inflamasi kornea merupakan tanda klinis yang penting dan sering ditemukan dalam kasus trauma kimia, keratitis herpes, penolakan graft kornea dan kondisi lainnya. Infiltrasi sel inflamasi, edema dan neovaskularisasi berhubungan dengan kekeruhan yang menetap dan kehilangan penglihatan (Rhobson, 2008). Di Amerika Serikat sekitar $4 \%$ populasi terjadi neovaskularisasi kornea dan setiap tahun 1,4 juta pasien beresiko terjadi neovaskularisasi kornea. Di Amerika Serikat juga terdapat sekitar 2,4 juta trauma okuler setiap tahunnya, dimana 20.000 sampai 68.000 dengan trauma yang mengancam penglihatan dan 40.000 orangmenderita kehiangan penglihatan yang signifikan setiap tahunnya (Kecova et al, 2011).

Trauma mata sering merupakan penyebab kebutaan unilateral pada anak dan dewasa muda, kelompok usia ini mengalami sebagian besar cedera mata yang parah. Kecelakaan di rumah, kekerasan, ledakan, cedera akibat olahraga, dan kecelakaan lalu lintas merupakan keadaan yang paling sering menyebabkan trauma mata. Trauma okuli kimia meliputi $26,5 \%$ dari seluruh trauma okuli. Lebih dari 23\% pasien mengalami kecacatan penglihatan bilateral permanen (Randleman, 2010). Kelompok yang beresiko tertinggi adalah laki-laki usia muda. Sebagian besar kecelakaan ini terjadi di tempat kerja atau rumah tangga. Trauma okuli akibat basa lebih sering terjadi daripada asam dan memerlukan terapi jangka panjang. Walaupun telah dilakukan penanganan medis yang maksimal sulit untuk mencapai rehabilitasi (Singh et al, 2013).

Trauma okuli khemis merupakan kedaruratan yang memerlukan pengenalan dan penanganan segera. Pengenceran agen kimia secara cepat merupakan penanganan yang diperlukan untuk mengurangi kerusakan jaringan dan mempertahankan penglihatan. Luasnya kerusakan mata sebanding dengan perbedaan $\mathrm{pH}$ bahan kimia dengan $\mathrm{pH}$ netral 7,4, lama waktu kontak, dan jumlah bahan kimia (James et al, 2010). Interleukin-8 (IL-8) adalah suatu faktor kemotaktik dan sitokin pro inflamasi yang dapat 
mengaktivasi neutrophil, basophil, dan T-cell. IL-8 juga terlibat dalam aktivasi neutrophil. IL-8 dilepaskan dari beberapa tipe sel sebagai bentuk respon terhadap adanya stimulus inflamasi. Peningkatam ekspresi dari IL8 menjadi indikator pertama inflamasi. Saraf kornea dalam epitel mengeluarkan substansi P yang akan merangsang IL-8. Substansi P juga merangsang dilatasi vaskuler, sekresi sitokin dan aktifasi leukocyte adhesion molecules. Sekresi sitokin ini yang akan mengawali proses angiogenesis di kornea (skov et al, 2008).

Genistein merupakan suatu komponen isoflavon yang berasal dari kedelai. Genistein berfungsi menghambat angiogenesis. Genistein mempunyai efek mengurangi neovaskularisasi kornea serta menurunkan kebocoran pembuluh darah, melewati mekanisme penghambatan protein tyrosine kinase yang merupakan komponen penting dalam kontrol jaringan biologis yang menentukan pertumbuhan dan diferensiasi sel (Pomfrey, 2005).

Penelitian ini dimaksudkan untuk mengetahui dan mengamati seberapa besar efek dari genistein terhadap ekspresi dari IL-8 yang ditimbulkan oleh reaksi inflamasi karena trauma kimia basa. Penelitian ini menggunakan kornea tikus (Rattus Novergicus Strain Wistar) yang di induksi dengan $\mathrm{NaOH} 1 \mathrm{M}$ (Molar) topikal agar terjadi reaksi inflamasi.

\section{METODE}

Rancangan penelitian yang digunakan pada penelitian ini adalah eksperimental dengan metode randomized double blind antara kelompok mata yang diterapi (perlakuan) dengan kelompok kontrol. Analisis ekspresi ekstrak dilaksanakan di Laboratorium Farmakologi Fakultas Kedokteran Universitas Muhammadiyah Malang. Pengukuran IL-8 kornea dilakukan di Laboratorium Biomedik Fakultas Kedokteran Universitas Brawijaya.

Penelitian ini menggunakan hewan coba Rattus novergicus strain wistar yang dipilih secara acak dengan kriteria inklusi sebagai berikut : (1) Jenis kelamin tikus jantan, (2) Tikus dewasa dengan umur antara 10-12 minggu, (3) Berat tikus antara 150-120 gram dan (4) Tikus sehat (aktif, bulu putih bersih, mata cerah dan tidak cacat). Kriteria eksklusi adalah sampel mati selama perlakuan, infeksi kornea yang ditandai dengan adanya sekret pada mata tikus.

Alat dan bahan penelitian meliputi jarum suntik 30gauge, gunting, pinset, mikroskop cahaya, sarung tangan steril, jas laboratorium, coverglass slide, pantocain $0,5 \%$, ketamine hydrochloride, aquadest, genistein serbuk, alkohol dengan konsentrasi 30\%, 50\%, 70\%, 80\%, 96\% dan absolute, xylol, gelatin $5 \% \mathrm{dH} 2 \mathrm{O}$, PBS, staining kit, antibodi IL-8, loop.

Perlakuan sampel ( Dean dan Jinsuk, 2011) yaitu tikus putih dilakukan anaestesi intraperitoneal dengan ketamin hydrochloride $(50 \mathrm{mg} / \mathrm{KgBB})$. Kelompok kontrol negatif : aplikasi aquadest sentral kornea mata kanan sebanyak empat kali satu tetes/hari. Pada kelompok perlakuan : pada kornea sentral tikus ditempeli dengan kertas filter dengan diameter 5,5 $\mathrm{mm}$ yang telah direndam dalam larutan $1 \mathrm{M}$ $\mathrm{NaOH}$, selama 60 detik. Kornea tikus kemudian dibilas dengan BSS selama 2 menit, kemudian tikus dibagi menjadi empat kelompok perlakuan.
Kelompok 1(kontrol positif) : 5 kornea mata kanan tikus + aplikasi $\mathrm{NaOH} 1 \mathrm{M}$ pada sentral kornea selama 60 detik. Setelah itu diberikan aquadest sebanyak 4 kali 1 tetes perhari. Kelompok 2: 5 kornea mata kanan tikus + aplikasi $\mathrm{NaOH} 1 \mathrm{M}$ pada sentral kornea selama 60 detik. Setelah itu diberikan genistein tetes mata $1 \mathrm{mg} / \mathrm{ml}$ sebanyak 4 kali 1 tetes perhari. Kelompok 3: 5 kornea mata kanan tikus + aplikasi $\mathrm{NaOH} 1 \mathrm{M}$ pada sentral selama 60 detik. Setelah itu Setelah itu diberikan genistein tetes mata $0,5 \mathrm{mg} / \mathrm{ml}$ sebanyak 4 kali 1 tetes perhari. Kelompok 4 : 5 kornea mata kanan tikus + aplikasi NaOH $1 \mathrm{M}$ pada sentral kornea selama 60 detik. Setelah itu diberikan genistein tetes mata $0,25 \mathrm{mg} / \mathrm{ml}$ 4 kali 1 tetes perhari.

Data dianalisa dengan menggunakan uji one way Anova untuk membuktikan adanya perbedaan antara kontrol, konsentrasi pemberian genistein tetes topikal terhadap perubahan ekspresi IL-8 berdasarkan waktu perlakuan pada kornea tikus. Uji statistik dikatakan bermakna bila $\mathrm{p}<0.05$. Uji homegenitas sampel menggunakan menggunakan lavene statistic dan normalitas sampel mengunakan uji kolmogorofsmirnov. Jika didapatkan perbedaan, dilanjutkan dengan uji rentang ganda post hoc test (mutiple comparison, Tukey). Untuk mengetahui korelasi pengaruh konsentrasi pemberian genistein terhadap IL-8 digunakan ujikorelasi-regresi. Proses perhitungan dilakukan dengan bantuan perangkat lunak komputer program SPSS 16 for windows.

\section{HASIL DAN PEMBAHASAN}

Penelitian ini merupakan Post Test Only Control Group Design dengan menggunakan 25 tikus jantan putih (Rattus novergicus strain wistar) yang dibagi menjadi 5 kelompok yang terdiri dari 5 ekor sebagai kontrol negatif, 5 ekor kontrol positif, 5 ekor perlakuan dosis $0,25 \mathrm{mg} / \mathrm{ml}, 5$ ekor perlakuan konsentrasi $0,50 \mathrm{mg} / \mathrm{ml}, 5$ ekor perlakuan konsentrasi $1 \mathrm{mg} / \mathrm{ml}$. Kelompok kontrol positif dan perlakuan diobservasi pada $24 \mathrm{jam}$. Kontrol negatif dalam penelitian ini digunakan untuk acuan menghitung effective dose (ED), penelitian ini dilakukan di Laboratorium Patologi Anatomi dan Biokimia Fakultas Kedokteran Universitas Brawijaya Malang selama 9 hari, dimana 7 hari pertama merupakan proses adaptasi tikus, sedangkan penelitian utama dimulai dari hari kedelapan sampai hari kesembilan. Pada penelitian ini tidak ada subjek yang dieksklusi. Di akhir penelitian dilakukan penghitungan ekspresi IL-8 dengan pewarnaan DAB. Dari hasil pemeriksaan imunohistokimia dengan DAB didapatkan gambaran ekspresi IL-8 yang berwarna kecoklatan.

Gambaran ekspresi ini kemudian dihitung dan dianalisis statistik pada kelompok kontrol positif diperoleh rata-rata perubahan eskpresi IL-8 sebesar 16,00 dengan standart deviasi 1,73. Hal ini membuktikan bahwa $\mathrm{NaOH} 1 \mathrm{M}$ terbukti menginduksi inflamasi pada kornea. Pada perlakuan dengan pemberian genistein sebesar $0,25 \mathrm{mg} / \mathrm{ml}$ diperoleh rata-rata perubahan eskpresi IL-8 sebesar 11,60 dengan standart deviasi sebesar 0,54. Kondisi ini menunjukkan terjadinya penurunan perubahan eskpresi IL-8 pada sampel. Penurunan perubahan eskpresi IL-8 juga dialami oleh kelompok dengan pemberian genistein sebesar $0,5 \mathrm{mg} / \mathrm{ml}$ hingga mencapai rata-rata 4,00 dengan standart deviasi sebesar 0,70. Demikian pula pada 
kelompok pemberian genistein sebesar $1 \mathrm{mg} / \mathrm{ml}$, juga mengalami penurunan perubahan eskpresi IL-8 hingga mencapai 3,40 dengan standart deviasi sebesar 0,54.

Pada penelitian ini dilakukan beberapa uji statistik yang dapat digunakan untuk pengambilan keputusan berdasarkan data hasil penelitian yang diperoleh. Uji Oneway ANOVA dilakukan dengan tujuan untuk mengetahui perbedaan ratarata yang signifikan di antara beberapa perlakuan. Uji korelasi digunakan untuk menguji hubungan yang signifikan antara dosis pemberian genitein dengan perubahan eskpresi IL-8, sedangkan untuk mengetahui pengaruh di antara dosis pemberian genistein terhadap perubahan eskpresi IL-8 pada tikus diperlukan pengujian regresi. Berikut ini ditunjukkan grafik perubahan eskpresi IL-8 sel rata-rata pada masingmasing perlakuan.

Sebelum dilakukan uji One way ANOVA, perlu dilakukan terlebih dahulu pengujian asumsi yang melandasinya. Asumsi yang diperlukan pada uji Oneway ANOVA yaitu uji asumsi normalitas dan homogenitas. Hasil uji normalitas (lampiran) menunjukkan bahwa nilai signifikansi yang diperoleh lebih besar dari taraf nyata $(0,319>0,05)$ yang berarti bahwa distribusi data perubahan eskpresi IL-8 berdistribusi normal. Hasil uji homogenitas (lampiran) menunjukkan bahwa nilai signifikansi yang diperoleh lebih besar dari taraf nyata $(0,179>0,05)$ yang berarti varian data perubahan eskpresi IL-8 pada masing-masing perlakuan adalah homogen. Karena asumsi yang melandasi pengujian One way ANOVA telah terpenuhi, maka selanjutnya dapat dilakukan uji One way ANOVA.

Berdasarkan hasil analisis di atas, menunjukkan bahwa nilai signifikansi yang diperoleh lebih kecil dari taraf nyata $(0,000<0,05)$ sehingga dapat disimpulkan bahwa terdapat perbedaan yang signifikan rata-rata perubahan eskpresi IL-8 pada masing-masing perlakuan (pemberian genistein). Untuk mengetahui perlakuan mana yang berbeda dengan perlakuan yang lain maka selanjutnya dilakukan uji lanjut rentang berganda dengan HSD Tukey 5\%.

Notasi menunjukkan terdapat perbedaan diantara kelompok perlakuan. Perlakuan pada kelompok III (genistein $1 \mathrm{mg} / \mathrm{ml}$ ) pada penelitian ini memberikan rata-rata perubahan eskpresi IL-8 paling rendah dibandingkan dengan perlakuan yang lain. Sedangkan rata-rata perubahan eskpresi IL-8 tertinggi terdapat pada kelompok perlakuan kontrol positif (tanpa pemberian genistein). Kedua perlakuan ini berbeda signifikan, ditunjukkan dengan pemberian notasi yang berbeda. Terlihat pula antar masing-masing perlakuan juga menunjukkan notasi yang berbeda sehingga dapat disimpulkan bahwa semua perlakuan berbeda signifikan dengan perlakuan yang lain.

Pada uji korelasi pearson didapatkan nilai signifikansi sebesar 0,000. Nilai ini lebih kecil dari taraf nyata 5\%, yaitu tingkat kesalahan yang ditentukan sebelum penelitian, yang berarti terdapat hubungan yang signifikan antara kenaikan dosis genistein terhadap perubahan eskpresi IL-8. Nilai korelasi yang terbentuk sebesar -0,884. Tanda negatif pada nilai korelasi menunjukkan hubungan yang terjadi antara kenaikan dosis genistein dengan perubahan eskpresi IL-8 berbanding terbalik. Artinya semakin tinggi dosis genistein yang diberikan pada kornea tikus, akan semakin menurunkan eskpresi IL-8 pada tikus tersebut. Nilai ini berada pada kriteria hubungan yang sangat kuat karena berada pada skala $0,800-1,000$.

Berdasarkan uji regresi linier (lampiran) didapatkan nilai signifikansi sebesar $0,000(p<0,01)$ dan nilai R2 sebesar 0,781 . Nilai R2 menunjukkan besarnya pengaruh pemberian dosis genistein terhadap perubahan ekspresi IL-8. Pengaruh pemberian genistein terhadap penurunan perubahan eskpresi IL-8 sebesar $0781(78,1 \%)$. Sedangkan pengaruh sisanya yaitu sebesar $21,9 \%$ penurunan perubahan eskpresi IL-8 dipengaruhi oleh faktor lain yang tidak diteliti yaitu antiinflamasi endogen seperti thrombospondin, angiostatin dan endostatin.

Berdasarkan hasil penelitian dan analisis data menunjukkan bahwa pemberian genistein topikal tetes mata dapat menurunkan ekspresi IL-8 pada tikus putih jantan (Rattus novergicus strain wistar) model inflamasi. Hal ini sesuai dengan penelitian (Li,H dkk, 2009) menyatakan bahwa genistein dapat menghambat ekspresi IL-8 pada sel-sel epitel pada retina yang akan menyebabkan terjadinya neovaskularisasi pada retina. Proses neovaskularisasi merupakan proses kelanjutan dari proses inflamasi dan IL8 memegang peranan yang sangat penting dalam proses neovaskularisasi. Ketika dilakukan perlakuan genistein 5 $\mathrm{mg} / \mathrm{ml}$ menunjukkan terjadi penurunan terhadap ekspresi IL-8. Hasil dari penurunan ekspresi IL-8 pada sel epitel retina ini terjadi karena efek dari genistein sebagai penghambat neovaskularisasi pada retina (Li et al, 2009). Sedangkan pada penelitian peneliti hanya sebatas meneliti tentang ekspresi IL-8 dalam proses inflamasi.

Pada penelitian Louis, S dan O’Brien, J (2004) juga menyatakan bahwa genistein juga terlibat dalam proses penghambatan dari transkripsi NF-?B yang dapat menyebabkan angiogenesis dan neovaskularisasi pada retina. Angiogenesis merupakan proses terbentuknya pembuluh darah baru sebagai akibat dari reaksi inflamasi yang melibatkan banyak mediator-mediator inflamasi yang salah satunya IL8. Genistein terlibat dalam jalur utama dari mekanisme penghambatan NF-?B serta menghambat mediator inflamasi yang dapat memicu terjadinya proses angiogenesis akibat dari adanya inflamasi (Louis S dan O'Brien J, 2004).

Selain itu, (Jinchao, L dkk, 2014) juga menyatakan bahwa dalam penelitiannya bahwa genistein dapat menurunkan ekspresi dari IL-1 $\alpha$, IL-6, dan IL-8 yang diproduksi oleh TNF- $\beta$. TNF- $\alpha$ merupakan mediator yang memegang peranan penting dari aktivasi dan produksi dari sitokin proinflamasi seperti IL-1 $\beta$, IL-6, dan IL-8. Pada penelitian ini menyatakan bahwa ekstrak protein kedelai yang mengandung genistein dapat menghambat dan menurunkan ekspresi dari sitokin proinflamasi IL-1 $\beta$, IL-6, dan IL-8 yang menyebabkan reaksi inflamasi pada penderita rheumatoid arthritis (Jinchao et al, 2014).

Sitokin pro-inflamasi yang dipilih dalam penelitian ini adalah IL-8. Interleukin-8 adalah salah satu mediator dan sitokin inflamasi yang dapat menyebabkan proses inflamasi. Pada kornea sehat, kita tidak mungkin menemukan IL-8 dalam keratosit dengan immunocy tochemistry. Beberapa penelitian telah menunjukkan bahwa paparan IL-8 dapat menginduksi keratosit untuk menghasilkan IL-8 melalui loop. Dengan demikian, dalam perlukaan kornea, IL-8 
dapat terdeteksi di dalam keratosit atau myofibroblast (Muhsin dan Ebru, 2009).

Induksi inflamasi pada penelitian ini menggunakan $\mathrm{NaOH} 1 \mathrm{M}$. Induksi dilakukan dengan cara menempelkan kertas saring yang sudah dicelupkan ke dalam larutan $\mathrm{NaOH}$ $1 \mathrm{M}$ di puncak kornea selama 60 detik. Tanda induksi yang berhasil adalah munculnya warna keputihan pada tempat induksi. Terdapat beberapa cara menginduksi respon inflamasi yaitu dengan AgNO3, $\mathrm{NaOH}$, dan aplikasi lempeng bFGF pada stroma kornea (Joussen, M.A dkk, 2005). Pada penelitian ini dipilih $\mathrm{NaOH}$ karena metode lebih sederhana dan lebih mudah dibandingkankan plate bFGF dan paling poten menginduksi inflamasi dibandingkan AgNO3. Respon inflamasi mulai tampak pada 3-6 jam setelah aplikasi $\mathrm{NaOH}$. Pada studi prelieliminary yang dilakuan menunjukkan bahwa induksi $\mathrm{NaOH} 1 \mathrm{M}$ memberikan respon inflamasi berupa warna keputihan pada puncak induksi, hyperemia, blefarospasme (Joussen et al, 2005).

Berdasarkan hasil analisis data, nilai korelasi yang terbentuk sebesar $-0,884$ yang berarti pengaruh pemberian genistein terhadap penurunan perubahan eskpresi IL-8 sebesar 0781 (78,1\%). Sedangkan pengaruh sisanya yaitu sebesar $21,9 \%$ penurunan perubahan eskpresi IL-8 dipengaruhi oleh faktor lain yang tidak diteliti yang mungkin berasal dari anti-inflamasi endogen seperti thrombospondin, angiostatin, dan endostatin. Ketiga anti-inflamasi endogen tersebut didapatkan juga pada kornea, sehingga mempengaruhi ekspresi IL-8. Thrombospondin merupakan anti-inflamasi endogen. Selain thrombospondin, (Balamurali, A.K dkk, 2004) menyebutkan dalam penelitiannya bahwa angiostatin juga sebagai anti-angiogenesis yang berfungsi untuk menghambat beberapa faktor yang menyebabkan neovaskularisasi seperti IL-1â, IL-6, IL-8 (Balamurali et al, 2004). Endostatin juga merupakan anti-angiogenesis yang berfungsi menghambat IL-1â, IL-6, IL-8 yang sering dimanfaatkan dalam penghambatan proses-proses seperti inflamasi dan pertumbuhan tumor (Amir et al , 2004).

Di dalam penelitan ini, peneliti tidak dapat memisahkan berbagai kandungan dalam genistein sehingga kemungkinan faktor fitoesterogen di dalam genistein juga berpengaruh dalam penurunan ekspresi IL-8 pada inflamasi kornea mata tikus putih jantan (Rattus novergicus strain wistar). Keterbatasan penelitian ini adalah dosis yang dipakai belum efektif karena hasil penghitungan ekspresi IL-8 belum mencapai nilai normal, serta belum dilakukan uji toksisitas untuk mengetahui dosis toksik genistein topikal tetes mata dan efek lain serta efek samping genistein topikal tetes mata dalam menurunkan ekspresi IL-8 pada inflamasi kornea mata tikus putih jantan (Rattus novergicus strain wistar).

\section{SIMPULAN}

Terdapat penurunan ekspresi IL-8setelah pemberian genistein pada kornea tikus putih jantan (Rattus novergicus strain wistar)model inflamasi yang diinduksi $\mathrm{NaOH} 1 \mathrm{M}$. Terdapat korelasi penurunan ekspresilL-8dengan pemberian genistein topikal tetes mata dengan dosis $0,25 \mathrm{mg} / \mathrm{ml}, 0,50$ $\mathrm{mg} / \mathrm{ml}$ dan $1 \mathrm{mg} / \mathrm{mlpada}$ kornea tikus putih jantan (Rattus novergicus strain wistar) model inflamasiyang diinduksi $\mathrm{NaOH} 1 \mathrm{M}$. Dosis efektif untuk penurunan ekspresi IL8pada penelitian ini adalah $1 \mathrm{mg} / \mathrm{ml}$.

\section{DAFTAR PUSTAKA}

Kecova H, Hlinomazova Z, Rauer P, Necas A.2004.Corneal Inflammatory Diseases - Infectious Keratitis in Dogs. Acta Vet BRNO 73:359-63

Wei, HZ, Zhu, Z.L.2009.Inhibition of experimental alkali induced corneal neovascularization in rabbit using genistein. Int Journal Ophthalmology. Vol 2 no 9.;123-125

Nicodemus Ezeh, M. Omogoye, E. Akirinde. 2007. Aluminum Influence on Performance of Some Cowpea (Vigna unguiculata) Varieties on a Nigerian Alfisol. World Journal of Agricultural Sciences 3 (4): 517522

Rhobson, Joe. 2008. Occular Trauma Management. http:// .opt.pacificu.edu. Diakses tanggal 29 Juni 2014

James B, Chew C dan Bron A, 2010. Eye Injury. http:// www.losangeleyeinjury.com. Diakses tanggal 29 Juni 2014

Rihawi, S., Frentz, M., Schrage, NF. 2006. "Emergency Treatment of Eye Burns: which rinsing solution should we choose?". Graefe's Arch Clin Exp Ophtalmology 244: 845-854.

Riordan-Eva, P., 2010. Anatomi \& Embriologi Mata. In: Vaughan, Asbury. Oftalmologi Umum Edisi 17. Jakarta: EGC:;45-46

Biswell, R., 2010. Kornea. In: Vaughan, Asbury. Oftalmologi Umum Edisi 17. Jakarta: EGC.;87-90

Bangun, C.Y.Y., 2009. Prevalensi Kebutaan Akibat Kelainan Kornea di Kabupaten Langkat. Departemen Ilmu Kesehatan Mata Fakultas Kedokteran Universitas Sumatera Utara RSUP. H. Adam Malik.;3-5

Ilyas, S., 2009. Kedaruratan Dalam Ilmu Penyakit Mata. Jakarta: Balai Penerbit FKUI.;74-77

Melsaether, CN, Rosenm, CL. "Burns, Ocular." EMedicine: The Continually Updated Clinical Reference. 1 Nov. 2007. 07 May 2009 http://emedicine.medscape.com/ article/7986966. Diakses pada tanggal 29 Juni 2014.

Sharma, A, Smilkstein, MJ, Fraufelder, FW. 2006. Ophthalmic principles. In: Goldfrank's toxicologic emergencies. New York : McGraw-Hill

Randleman, JB. 2010. Chemial eye burn overview. http:// www.emedicine.com Diakses pada tanggal 29 Juni 2014.

Tantin D, Jinsuk. 2011. Protocol for Immunostaining Cells for Microscopy

Eraslan M, Toker E. 2009. Mechanisms of Corneal Wound Healing and its Modulation Following Refractive Surgery. Marmara Medical Journal ;22(2);169-178

Kimura K. 2014. Mechanisms of Corneal Damage Associated with Ocular Surfac Inflammation. 60(3-4); 47-55

Skov L, Beurskens F.J, Zachariae C.O.C, Reitamo S, Teeling J, Satijn D, Knudsen K.M, Boot E.P.J, Hudson D, Baadsgaard O, Parren P.W.H.I, Winkel J.G.J .2008 .IL8 as Antibody Therapeutic Target in Inflammatory Diseases: Reduction of Clinical Activity in Palmoplantar Pustulosis. Journal of Immunology 181;669-679

Singh P, Tyagi M, Kumar Y, Gupta K.K, Sharma P.D.2013. Ocular Chemical Injuries and Their Management. Oman Journal of Ophthalmology, Vol. 6, No. 2:8385 
Pomfrey. Genistein: A Multichanistic Anti-cancer agent from Soya.2005. vivienpomfrey.co.uk/.p 1-25 diakses tanggal 29 Juni 2014:22-24

Taylor K.C, Levy R.M, Elliot J.C, Burnett B.P.2009. The Effect of Genistein Aglycone on Cancer and Cancer Risk: a Review of in vitro, Preclinical, and Clinical Studies. doi:10.1111/j.1753-4887

Kim E.K, Kwon K.B, Song M.Y, Seo S.W, Park S.J, Ka S.O, Na L, Kim K.A, Ryu D.G, So H.S, Park R, Park J.W, Park B.H.2007. Genistein Protects Pancreatic Beta Cells Against Cytokine-Mediated Toxicity.;278(1-2):18 28

Castro SB, Junior CO, Souza A.C, Dias AT, Juliano MA, Castañon MC, Almeida MV, Teixeira HC and Ferre ira A .2013. Genistein derivatives down-modulates pro-inflammatory cytokines in activated J774A.1 cells and reverses clinical signs of experimental autoimmune encephalomyelitis. doi: 10:3389

Sakai T, Kogiso M, Mitsuya K, Komatsu T, Yamamoto S. 2006. Genistein Enhances Antigen-Specific Cytokine Production in Female DO11.10 Transgenic Mice. Journal of Nutrition Sci Vitaminol 52, 327-332

Kosoko A, Vu Q, Lasaki O.K. 2009. Chemical Ocular Burns : A Case Review. American Journal of Clinical Medicine. Vol .6, No. 3:43-46

Mircheff A.K. 2010. Adaptive Immune System and the Eye : Mucosal Immunity:35-36

Lawrence T. 2009. The Nuclear Factor NF-kB Pathway in Inflammation:4-6 